\title{
Pengaruh Leverage, Pertumbuhan Penjualan, dan Ukuran Perusahaan Terhadap Tax Avoidance
}

\author{
Salma Mustika Ainniyya ${ }^{{ }^{*}}$, Ati Sumiati ${ }^{2}$, Santi Susanti ${ }^{3}$ \\ 1,2,3 Universitas Negeri Jakarta, Indonesia \\ salmamustika@gmail.com, atis.june@gmail.com, ssusanti@unj.ac.id
}

*Penulis Koreponden

Diajukan : :04 Juni 2021

Disetujui : :09 Juli 2021

Dipublikasi : 2 Agustus 2021

\begin{abstract}
Tax Avoidance is an act to avoid taxes by companies that can reduce tax revenue for the state. This study aims to examine the effect of Leverage, Sales Growth, and Company Size on Tax Avoidance. Population in this study were all companies listed in Indonesia Stock Exchange for 2018 - 2019 period. Purposive sampling used as sampling technique and obtained 219 companies as samples. This study used quantitative method and the analysis was multiple linear regression analysis. Tax Avoidance proxied by Effective Tax Rate which have a negative interpretation of Tax Avoidance. The result of $t$ test shows that Leverage has a significant effect on Tax Avoidance, positive relationship between Debt to Equity Ratio as proxy for Leverage and Effective Tax Rateas proxy for Tax Avoidance explains that the higher the Leverage, the lower the Tax Avoidance. Sales Growth has a significant effect on Tax Avoidance, negative relationship between sales growth and Effective Tax Rate explains that the higher the Sales Growth, the higher the Tax Avoidance. While Company Size has no significant effect on Tax Avoidance, bigger or smaller the Company Size will not have any effect on Tax Avoidance. The f test shows that Leverage, Sales Growth, and Company Size simultaneously have a significant effect on Tax Avoidance. Result of adjusted $R$ square shows that the effect of Leverage, Sales Growth, and Company Size on Tax Avoidance is 0,072 or 7,2\%.
\end{abstract}

Keywords: Company Size; Effective Tax Rate; Leverage; Sales Growth; Tax Avoidance

\section{PENDAHULUAN}

Seiring berjalannya waktu, Indonesia menjalani perkembangan pesat yang disertai dengan kemajuan dalam bidang usaha. Pada akhir tahun 2020 terlihat 712 perusahaan yang telah tercatat dalam Bursa Efek Indonesia (BEI). Selain itu, berdasarkan Sensus Ekonomi oleh Badan Pusat Statistik (BPS) pada tahun 2016, terlihat sebanyak 26.422.256 usaha di Indonesia yang terdiri dari 26.073.698 Usaha Menengah Kecil dan 348.567 Usaha Menengah Besar (BPS, 2016). Dari banyaknya usaha-usaha tersebut maka diharapkan pendapatan pajak oleh negara akan meningkat.

Bagi negara dan masyarakatnya, pajak memiliki peranan yang sangat penting. Pajak juga sangat berpengaruh dalam kemajuan suatu negara karena dapat digunakan sebagai pembiayaan untuk pendidikan, pembangunan infrastruktur, bantuan sosial, dan kegiatan negara lainnya. Pajak sendiri memiliki beberapa fungsi diantaranya ialah fungsi anggaran, fungsi mengatur, fungsi stabilitas, dan juga fungsi redistribusi pendapatan (Pramukti \& Primaharsya, 2015).

Pendapatan terbesar bagi negara adalah penerimaan dari sektor pajak. Dalam APBN 2020 yang tertera dalam Peraturan Presiden No. 72 Tahun 2020, total target pendapatan pajak adalah sebesar Rp1.404 triliun dari total target pendapatan negara dan hibah sebesar Rp1.699 triliun. Berdasarkan hal tersebut terlihat sebagian besar pendapatan negara berasal dari sektor pajak yaitu senilai $82,6 \%$.

Pada kegiatan pemungutan pajak, terdapat tujuan yang berbeda antara pemerintah sebagai pihak pemungut pajak dan perusahaan sebagai pihak pembayar pajak. Pemerintah menghendaki pendapatan pajak yang tinggi sebagai sumber pembiayaan terbesar bagi pelaksanaan kegiatan negara. Sedangkan bagi perusahaan, pajak ialah suatu kewajiban yang memberatkan dan beban yang dapat mengurangi labanya. Sehingga perusahaan akan berusaha untuk meminimalkan pembayaran pajaknya. 
Perbedaan tujuan atau kepentingan dari sisi pemerintah dan perusahaan menimbulkan adanya perlawanan dari wajib pajak. Perlawanan pajak ialah tindakan disengaja atau tidak untuk menghindari, mengelak pajak, dan tidak membayar pajak yang dikategorikan menjadi perlawanan pasif dan perlawanan aktif (Setyawan, 2020). Salah satu perlawanan aktif yang dilakukan wajib pajak ialah dengan melakukan tax avoidance yaitu penghindaran pajak dengan cara memanfaatkan celah kebijakan pajak.

Tindakan tax avoidance akan berdampak pada penerimaan pajak oleh pemerintah. Pajak yang diterima akan menurun akibat para wajib pajak yang berusaha untuk menghindari pajak. Laporan yang dikeluarkan oleh Tax Justice Network memperlihatkan adanya penerimaan pajak yang hilang sebesar US\$427 miliar/tahun secara global, dan Indonesia merugi sebesar US\$4,864 miliar/tahun akibat adanya tax avoidance (Tax Justice, 2020).

Salah satu cara perusahaan dalam melakukan penghindaran pajak ialah dengan memperbesar utangnya. Tingginya utang akan menimbulkan beban bunga yang tinggi sehingga akan mengurangi beban pajak. Beban pajak akan mengurangi profit dan berkurangnya profit akan mengurangi beban pajak dalam satu periode (Kimsen, Kismanah, \& Masitoh, 2018). Tingginya tingkat utang perusahaan dapat diperlihatkan melalui rasio yang dinamakan leverage. Penelitian (Tristianto \& Oktaviani, 2016) menemukan hasil leverage secara positif berpengaruh terhadap tax avoidance. Penelitian (Dewi \& Noviari, 2017) menemukan hasil leverage secara negatif berpengaruh terhadap tax avoidance. Sementara (Arianandini \& Ramantha, 2018) menemukan hasil leverage tidak berpengaruh terhadap tax avoidance.

Hal yang dapat membuat perusahaan cenderung melakukan tax avoidance ialah pertumbuhan penjualan. Semakin tinggi pertumbuhan penjualan akan mengakibatkan bertambahnya pendapatan kena pajak yang akan membuat beban pajak semakin tinggi. Dalam setiap periode, perusahaan akan berusaha semaksimal mungkin untuk meningkatkan penjualannya. Hal ini dikarenakan pertumbuhan penjualan sangat penting, karena omzet penjualan ialah ujung tombak perusahaan (Budiman, 2018). Penelitian (Januari \& Suardikha, 2019) menemukan hasil pertumbuhan penjualan secara positif berpengaruh terhadap tax avoidance. Sementara (Mahdiana \& Amin, 2020) menemukan hasil pertumbuhan penjualan tidak berpengaruh terhadap tax avoidance.

Setiap perusahaan memiliki cara masing-masing dalam melakukan manajemen pajaknya. Perusahaan berskala besar memiliki kemampuan yang lebih tinggi dalam melakukan manajemen pajaknya. Namun, semakin besar skala perusahaan juga akan menjadi fokus pemerintah dalam melakukan pemungutan pajaknya. Sehingga skala ukuran tiap-tiap perusahaan dapat mempengaruhi cara perusahaan memanajemen pajaknya. Penelitian (Irianto, Sudibyo, \& Wafirli, 2017) menemukan hasil ukuran perusahaan secara positif berpengaruh terhadap tax avoidance. Penelitian (Tristianto \& Oktaviani, 2016) menemukan hasil ukuran perusahaan secara negatif berpengaruh terhadap tax avoidance. Sementara (Merslythalia \& Lasmana, 2016) menemukan hasil ukuran perusahaan tidak berpengaruh terhadap tax avoidance.

Penelitian sebelumnya berkaitan dengan tax avoidance memiliki hasil dan kesimpulan yang banyak ragamnya. Bervariasinya hasil penelitian terdahulu mendatangkan ketertarikan bagi peneliti untuk melakukan penelitian ini yang bertujuan untuk mengetahui pengaruh antara leverage, pertumbuhan penjualan, dan ukuran perusahaan terhadap tax avoidance secara parsial maupun simultan. Sehingga dengan adanya penelitian ini, para pihak berkepentingan dapat mengetahui beberapa faktor yang dapat mempengaruhi tingkat tax avoidance perusahaan yang menyebabkan berkurangnya pendapatan dari sektor pajak.

\section{STUDI LITERATUR}

Teori agensi menjelaskan adanya kepentingan yang bertentangan diantara manajer dengan pemilik (Sudaryo, Sjarif, \& Sofiati, 2017). Perbedaan kepentingan tersebut menjadikannya suatu masalah yang disebut sebagai masalah keagenan. Masalah keagenan disebabkan adanya perbedaan tujuan dari dua pihak yang berkepentingan yaitu agent dan principal (Anwar, 2019). Dalam kaitannya dengan tax avoidance, masalah agensi timbul dari adanya perselisihan kepentingan pemerintah selaku pemungut pajak dengan perusahaan selaku pembayar pajak. Hal tersebut dikarenakan pemerintah ingin memaksimalkan pendapatan dari sektor pajak, sedangkan perusahaan sebagai wajib pajak ingin meminimalkan pengeluaran untuk pajak. 
Banyak cara yang dimanfaatkan perusahaan untuk meminimalkan pengeluaran pajak, satu diantaranya adalah dengan tax avoidance. Tax avoidance itu sendiri dikatakan sebagai usaha penghindaran pajak secara legal dan aman oleh wajib pajak dan tidak berlawanan dengan ketentuan pajak yang berlaku (Pohan, 2018). Tujuan utama dilakukannya tax avoidance adalah untuk memperkecil pajak sehingga perusahaan bisa mendapatkan laba yang maksimal. Penghindaran pajak yang dilakukan melalui tax avoidance dianggap tidak berselisih dengan hukum yang berlaku, oleh karenanya cara tersebut dikatakan legal (Farouq, 2018).

Leverage ialah penggambaran kesanggupan perusahaan untuk pemenuhan kewajibannya. Rasio leverage ialah rasio yang digunakan dalam pengukuran kemampuan perusahaan untuk memenuhi seluruh kewajibannya, baik kewajiban jangka pendek ataupun jangka panjang (Hery, 2015). Leverage mampu mempertunjukkan seberapa jauh pembiayaan perusahaan oleh utang dengan kemampuan perusahaan yang diperlihatkan oleh modal (Harahap, 2016). Tingginya tingkat leverage menandakan bahwa perusahaan lebih bergantung pada pendanaan dari utang. Semakin tinggi utang, maka akan timbul beban bunga yang tinggi pula. Beban bunga tersebut menjadi salah satu keuntungan bagi perusahaan untuk mengurangi pajaknya. Perusahaan dengan leverage tinggi cenderung melakukan tax avoidance karena insentif pajak atas beban bunga yang diperoleh perusahaan dalam mengurangi beban pajak (Ariawan \& Setiawan, 2017). Hal ini diperkuat oleh penelitian (Dewi \& Noviari, 2017; Dharma \& Ardiana, 2016; Kim \& Im, 2017; Tristianto \& Oktaviani, 2016) yang menyatakan bahwa leverage memiliki pengaruh terhadap tax avoidance.

Pertumbuhan penjualan merupakan salah satu rasio pertumbuhan yang berguna untuk pengukuran kinerja penjualan perusahaan. Kesanggupan perusahaan untuk menambah tingkat penjualan dari periode ke periode lainnya dapat ditunjukkan melalui pertumbuhan penjualan (Oktamawati, 2017). Pertumbuhan penjualan juga dapat digunakan untuk memprediksi perolehan laba perusahaan (Fauzan, Wardan, \& Nurharjanti, 2019). Nilai pertumbuhan penjualan yang positif menandakan bahwa perusahaan mengalami peningkatan penjualan dari periode sebelumnya. Besarnya penjualan akan mempengaruhi besarnya laba, maka beban pajak juga akan semakin besar sehingga pertumbuhan penjualan berpengaruh atas tax avoidance (Purwanti \& Sugiyarti, 2017). Hal ini diperkuat oleh penelitian (Januari \& Suardikha, 2019; Kim \& Im, 2017; Puspita \& Febrianti, 2017; Tristianto \& Oktaviani, 2016) yang menyatakan bahwa pertumbuhan penjualan memiliki pengaruh terhadap tax avoidance.

Ukuran perusahaan ialah pengukuran yang digolongkan berdasar pada besar atau kecilnya perusahaan, selain itu juga mampu memperlihatkan kegiatan operasional dan pendapatan perusahaan (Mahdiana \& Amin, 2020). Pengklasifikasian perusahaan dapat dilakukan menjadi perusahaan kecil, menengah, dan besar sesuai dengan cara pengukurannya masing-masing. Perusahaan besar cenderung memanfaatkan opsi akuntansi yang mengurangi pelaporan laba dibandingkan perusahaan kecil (Sulistyanto, 2018). Hal tersebut dikarenakan perusahaan yang berskala besar cenderung memperoleh laba yang lebih tinggi apabila dipadankan dengan perusahaan kecil, sehingga akan sangat memengaruhi pajak perusahaan. Hal ini diperkuat oleh penelitian (Dharma \& Ardiana, 2016; Irianto et al., 2017; Nibras \& Hadinata, 2020; Tristianto \& Oktaviani, 2016) yang menyatakan bahwa ukuran perusahaan memiliki pengaruh terhadap tax avoidance.

Leverage, pertumbuhan penjualan, dan ukuran perusahaan merupakan beberapa aspek yang memiliki keterkaitan dengan tax avoidance. Faktor finansial yang berhubungan dengan tax avoidance diantaranya yaitu kinerja keuangan, intensitas aktiva, ukuran perusahaan, kompensasi kerugian, kompensasi bagi eksekutif, CSR, kepemilikan saham eksekutif, dan financial distress (Rahayu, 2020). Hal ini diperkuat oleh penelitian (Kim \& Im, 2017) yang mengemukakan bahwa karakteristik keuangan yang berhubungan dengan tax avoidance yaitu firm size, leverage, capital intensity, profitability, operating cash flow, sales growth, $R \& D$ intensity, dan export rate.

Berdasarkan penguraian di atas, maka hipotesis dalam penelitian ini yaitu:

$\mathrm{H}_{1}$ : Leverage berpengaruh terhadap Tax Avoidance

$\mathrm{H}_{2}$ : Pertumbuhan Penjualan berpengaruh terhadap Tax Avoidance

$\mathrm{H}_{3}$ : Ukuran Perusahaan berpengaruh terhadap Tax Avoidance

$\mathrm{H}_{4}$ : Leverage, Pertumbuhan Penjualan, dan Ukuran Perusahaan berpengaruh terhadap Tax Avoidance 


\section{METODE}

Penelitian ini dilakukan dengan pendekatan kuantitatif. Penelitian kuantitatif pada dasarnya ialah pengumpulan data numerik untuk menjelaskan fenomena tertentu (Duli, 2019). Tujuan dilakukannya penelitian ini adalah untuk mengetahui pengaruh dari leverage, pertumbuhan penjualan, dan ukuran perusahaan terhadap tax avoidance.

Perusahaan yang terdaftar di BEI periode tahun 2018 - 2019 terpilih menjadi populasi untuk penelitian ini. Teknik pemilihan sampel yang diterapkan dalam penelitian ini ialah purposive sampling, yaitu pemilihan sampel yang meliputi responden, subjek, atau elemen yang terpilih lantaran adanya karakteristik tertentu (Morissan, 2017). Kriteria dalam pemilihan sampel untuk penelitian ini yaitu:

Tabel 1. Hasil Pemilihan Sampel

\begin{tabular}{|c|l|c|}
\hline No. & \multicolumn{1}{|c|}{ Kriteria } & Jumlah \\
\hline 1. & Perusahaan yang terdaftar di BEI & 712 \\
\hline 2. & $\begin{array}{l}\text { Perusahaan yang tidak secara konsisten terdaftar di BEI selama } \\
\text { periode 2018 - 2019 }\end{array}$ & $(105)$ \\
\hline 3. & $\begin{array}{l}\text { Perusahaan yang tidak menerbitkan laporan keuangan tahunan } \\
\text { selama periode 2018-2019 }\end{array}$ & $(19)$ \\
\hline 4. & $\begin{array}{l}\text { Perusahaan yang tidak memiliki tanggal akhir periode 31 } \\
\text { Desember pada laporan keuangan }\end{array}$ & $(8)$ \\
\hline 5. & $\begin{array}{l}\text { Perusahaan yang memiliki saldo ekuitas negatif selama periode } \\
\text { 2018-2019 }\end{array}$ & $(24)$ \\
\hline 6. & Perusahaan yang tidak memiliki saldo penjualan & $(83)$ \\
\hline 7. & Perusahaan yang mengalami kerugian selama periode 2018-2019 & $(155)$ \\
\hline \multicolumn{1}{|c|}{ Jumlah Sampel } & $\mathbf{2 1 9}$ \\
\hline
\end{tabular}

Sumber: Data Diolah Peneliti (2021)

Proxy untuk perhitungan tax avoidance selaku variabel dependen $(\mathrm{Y})$ pada penelitian ini ialah dengan Effective Tax Rate (ETR). ETR memiliki interpretasi negatif dengan tax avoidance. Hal ini mengartikan bahwa tingginya ETR menandakan rendahnya tax avoidance perusahaan dan begitu pula sebaliknya. Perusahaan dengan ETR rendah lebih agresif kepada pajak dibandingkan perusahaan dengan ETR yang tinggi (Tang, 2020, p. 334). Perhitungan ETR yaitu sebagai berikut:

$$
\mathrm{ETR}=\frac{\text { Beban Pajak }}{\text { Laba Sebelum Pajak }}
$$

Selanjutnya, proxy untuk leverage selaku variabel independen pertama $\left(\mathrm{X}_{1}\right)$ pada penelitian ini ialah dengan Debt to Equity Ratio (DER). DER mengunjukkan perbandingan antara penggunaan sumber dari utang terhadap sumber dana dari ekuitas (Lukman, 2018, p. 59). Perhitungannya sebagai berikut:

$$
\mathrm{DER}=\frac{\text { Total Utang }}{\text { Total Ekuitas }}
$$

Pertumbuhan penjualan selaku variabel independen kedua $\left(\mathrm{X}_{2}\right)$ pada penelitian ini diukur menggunakan rasio sales growth. Sales growth dapat mengunjukkan kinerja penjualan perusahaan dari satu periode ke periode lainnya. Perhitungannya sebagai berikut:

$$
\text { Sales Growth }=\frac{\text { Penjualan }_{\mathrm{n}}-\text { Penjualan }_{\mathrm{n}-1}}{\text { Penjualan }_{\mathrm{n}-1}}
$$

Ukuran perusahaan selaku variabel independen ketiga $\left(\mathrm{X}_{3}\right)$ dalam penelitian ini dihitung dari besarnya total aset milik perusahaan, sehingga semakin tinggi total aset menandakan semakin 
Owner: Riset \& Jurnal Akuntansi

e-ISSN : 2548-9224 |p-ISSN : 2548-7507

Volume 5 Nomor 2, Agustus 2021

DOI : https://doi.org/10.33395/owner.v5i2.453

besarnya ukuran perusahaan. Perhitungannya sebagai berikut:

$$
\text { Ukuran Perusahaan }=\text { Natural Log }(\text { Total Aset })
$$

Keperluan data untuk penelitian diperoleh secara sekunder. Data tersebut bersumber dari laporan keuangan tahunan milik perusahaan yang diakses dalam laman resmi BEI atau laman resmi tiap-tiap perusahaan. Data dikumpulkan dari laporan keuangan tahunan perusahaan untuk periode 2018 - 2019. Data untuk variabel tax avoidance dan pertumbuhan penjualan didapatkan dari laporan laba rugi, sedangkan data untuk variabel leverage dan ukuran perusahaan didapatkan dari laporan posisi keuangan.

Tahap awal penganalisisan data adalah dengan statistik deskriptif. Setelah itu dilakukan beberapa tahap uji lainnya yaitu asumsi klasik, regresi linear ganda, dan uji hipotesis. Uji asumsi klasik berupa normalitas, multikolinearitas, heteroskedastisitas, dan autokorelasi. Serta untuk pengujian hipotesis dilakukan uji t yang memperlihatkan pengaruh variabel secara parsial, uji $\mathrm{f}$ yang memperlihatkan pengaruh variabel secara simultan, juga uji koefisien determinasi.

\section{HASIL}

Hasil pengolahan data digambarkan secara umum melalui pendeskripsian data dengan statistik deskriptif. Pendeskripsian data dilakukan dengan nilai minimum, maksimum, mean, dan standar deviasi untuk tiap-tiap variabel.

Tabel 2. Statistik Deskriptif

\begin{tabular}{|l|c|r|r|r|r|}
\hline \multicolumn{7}{|c|}{ Descriptive Statistics } \\
\hline & \multicolumn{1}{|c|}{$\mathrm{N}$} & Minimum & \multicolumn{1}{|c|}{ Maximum } & \multicolumn{1}{c|}{ Mean } & Std. Deviation \\
\hline Leverage & 219 & .0230 & 6.3029 & .976771 & .8895910 \\
\hline Pertumbuhan Penjualan & 219 & -.3006 & 4.6962 & .185083 & .4823090 \\
\hline Ukuran Perusahaan & 219 & 24.6129 & 33.4841 & 28.821060 & 1.5352487 \\
\hline Tax Avoidance & 219 & .1183 & .3918 & .255960 & .0542841 \\
\hline Valid N (listwise) & 219 & & & & \\
\hline
\end{tabular}

Sumber: Output SPSS 26 (Data Diolah Peneliti, 2021)

Selanjutnya dilakukan uji normalitas pada data untuk melihat normalnya pendistribusian pada data yang diuji. Uji normalitas menggunakan Kolmogorov Smirnov dan Normal P Plot. Taraf signifikansi penelitian ini yaitu 5\% sehingga apabila nilai probabilitas melebihi 0,05 data dikatakan normal. Melalui Tabel 3. terlihat bahwa nilai Asymp. Sig. adalah 0,200. Hasil tersebut memperlihatkan bahwa nilai probabilitas lebih besar dari 0,05. Sehingga dari hasil uji tersebut dikatakan data berdistribusi normal.

Tabel 3. Uji Normalitas

\begin{tabular}{|l|l|r|}
\hline \multicolumn{2}{|c|}{ One-Sample Kolmogorov-Smirnov Test } \\
\hline $\mathrm{N}$ & Mean & Unstandardized Residual \\
\hline Normal & Std. Deviation & .0000000 \\
\cline { 2 - 3 } Parameters ${ }^{\mathrm{a}, \mathrm{b}}$ & Std & .05194570 \\
\hline Most & Absolute & .043 \\
Extreme & Positive & .042 \\
\cline { 2 - 3 } Differences & Negative & -.043 \\
\hline Test Statistic & .043 \\
\hline Asymp. Sig. (2-tailed) & $.200^{\mathrm{c}, \mathrm{d}}$ \\
\hline
\end{tabular}

Sumber: Output SPSS 26 (Data Diolah Peneliti, 2021) 
Owner: Riset \& Jurnal Akuntansi

e-ISSN : 2548-9224 |p-ISSN : 2548-7507

Volume 5 Nomor 2, Agustus 2021

DOI : https://doi.org/10.33395/owner.v5i2.453

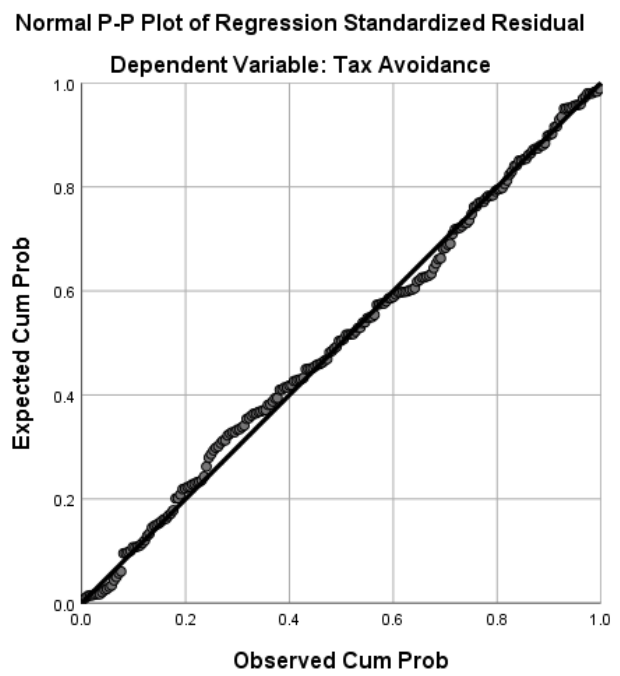

Gambar 1. Normal P-Plot

Sumber: Output SPSS 26 (Data Diolah Peneliti, 2021)

Berdasarkan Gambar 1. terlihat bahwa titik dalam Normal Probability Plot menyebar dan mengikuti arah diagonal garis. Penggunaan uji Kolmogorov Smirnov dan Normal P Plot untuj pengujian normalitas mendapatkan kesimpulan bahwa data berdistribusi normal.

Uji selanjutnya adalah multikolinearitas. Kriteria dari pengujian multikolinearitas yaitu dengan berpacu pada besarnya tolerance dan VIF. Jikalau tolerance mengunjukkan nilai lebih dari 0,10 dan VIF mengunjukkan nilai kurang dari 10,00 maka tercapai kesimpulan bahwa pada data yang diuji tidak terindikasi multikolinearitas.

Tabel 4. Uji Multikolinearitas

\begin{tabular}{|c|c|c|c|}
\hline \multicolumn{4}{|c|}{ Coefficients $^{\mathrm{a}}$} \\
\hline \multirow{2}{*}{\multicolumn{2}{|c|}{ Model }} & \multicolumn{2}{|c|}{ Collinearity Statistics } \\
\hline & & Tolerance & VIF \\
\hline \multirow[t]{4}{*}{1} & (Constant) & & \\
\hline & Leverage & .915 & 1.093 \\
\hline & Pertumbuhan Penjualan & .993 & 1.007 \\
\hline & Ukuran Perusahaan & .917 & 1.090 \\
\hline
\end{tabular}

Sumber: Output SPSS 26 (Data Diolah Peneliti, 2021)

Tabel 3. memperlihatkan besarnya tolerance untuk tiap-tiap variabel bernilai lebih dari 0,10 . Selanjutnya nilai dari VIF juga terlihat kurang dari 10,00. Uji multikolinearitas pada penelitian ini mendapatkan hasil bahwa ketiga variabel independen penelitian yaitu leverage, pertumbuhan penjualan, dan ukuran perusahaan terbebas dari adanya multikolinearitas.

Tabel 5. Uji Heteroskedastisitas

\begin{tabular}{|c|c|c|c|c|c|}
\hline \multicolumn{6}{|c|}{ Coefficients $^{\mathrm{a}}$} \\
\hline \multirow[t]{2}{*}{ Model } & \multicolumn{2}{|c|}{$\begin{array}{l}\text { Unstandardized } \\
\text { Coefficients }\end{array}$} & \multirow{2}{*}{$\begin{array}{l}\text { Standardized } \\
\text { Coefficients } \\
\text { Beta }\end{array}$} & \multirow[t]{2}{*}{$\mathrm{t}$} & \multirow[t]{2}{*}{ Sig. } \\
\hline & B & Std. Error & & & \\
\hline 1 (Constant) & .079 & .043 & & 1.841 & .067 \\
\hline Leverage & .001 & .003 & .026 & .367 & .714 \\
\hline Pertumbuhan Penjualan & -.001 & .005 & -.020 & -.294 & .769 \\
\hline Ukuran Perusahaan & -.001 & .002 & -.064 & -.897 & .371 \\
\hline
\end{tabular}

Sumber: Output SPSS 26 (Data Diolah Peneliti, 2021) 
Selanjutnya dilakukan uji heteroskedastisitas memakai uji Glejser. Ketika hasil perolehan nilai signifikansi lebih dari 5\% maka dalam data tidak terdapat heteroskedastisitas. Berdasar pada Tabel 4. terlihat bahwa nilai signifikansi untuk tiap-tiap variabel lebih besar dari 0,05 . Hasil uji tersebut menandakan bahwa data dari ketiga variabel independen terbebas dari heteroskedastisitas.

Tabel 6. Uji Autokorelasi

\begin{tabular}{|l|r|r|r|r|r|}
\hline \multicolumn{7}{|c|}{ Model Summary } \\
\hline Model & R & R Square & $\begin{array}{c}\text { Adjusted R } \\
\text { Square }\end{array}$ & $\begin{array}{c}\text { Std. Error of } \\
\text { the Estimate }\end{array}$ & $\begin{array}{c}\text { Durbin- } \\
\text { Watson }\end{array}$ \\
\hline 1 & $.290^{\mathrm{a}}$ & .084 & .072 & .0523069 & 1.965 \\
\hline
\end{tabular}

a. Predictors: (Constant), Ukuran Perusahaan, Pertumbuhan Penjualan, Leverage

b. Dependent Variable: Tax Avoidance

Sumber: Output SPSS 26 (Data Diolah Peneliti, 2021)

Uji asumsi klasik yang terakhir adalah autokorelasi dengan menggunakan uji Durbin Watson. Data terbebas dari autokorelasi baik negatif ataupun positif apabila nilai $\mathrm{dU}<\mathrm{d}<4-\mathrm{dU}$. Berdasarkan Tabel 5. terlihat bahwa perolehan nilai Durbin Watson ialah 1,9650. Tabel Durbin Watson dengan nilai signifikansi 0,05 menampakkan bahwa nilai dU adalah 1,8069. Sedangkan nilai $4-\mathrm{dU}$ sebesar 2,1931. Sehingga data ini memenuhi kriteria terbebas dari adanya autokorelasi baik negatif maupun positif karena $\mathrm{dU}<\mathrm{d}<4-\mathrm{dU}(1,8069<1,9650<2,1931)$.

Pengujian analisis regresi linear ganda memperlihatkan besaran pengaruh dari variabel independen terhadap variabel dependen. Regresi linear ganda dapat digunakan sebagai prediksi dari nilai variabel dependen apabila terdapat perubahan (naik atau turun) nilai dari variabel independen.

Tabel 7. Analisis Regresi Linear Berganda

\begin{tabular}{|c|c|c|c|c|c|c|}
\hline \multicolumn{7}{|c|}{ Coefficients $^{\mathrm{a}}$} \\
\hline \multirow{2}{*}{\multicolumn{2}{|c|}{ Model }} & \multicolumn{2}{|c|}{$\begin{array}{l}\text { Unstandardized } \\
\text { Coefficients }\end{array}$} & \multirow{2}{*}{$\begin{array}{c}\text { Standardized } \\
\text { Coefficients } \\
\text { Beta }\end{array}$} & \multirow[t]{2}{*}{$\mathrm{T}$} & \multirow[t]{2}{*}{ Sig. } \\
\hline & & B & Std. Error & & & \\
\hline \multirow[t]{4}{*}{1} & (Constant) & .377 & .069 & & 5.501 & .000 \\
\hline & Leverage & .016 & .004 & .267 & 3.917 & .000 \\
\hline & Pertumbuhan Penjualan & -.017 & .007 & -.148 & -2.255 & .025 \\
\hline & Ukuran Perusahaan & -.005 & .002 & -.132 & -1.930 & .055 \\
\hline
\end{tabular}

Sumber: Output SPSS 26 (Data Diolah Peneliti, 2021)

Berdasarkan hasil analisis dalam Tabel 7. persamaan regresi linear berganda yang didapatkan yaitu:

$$
\mathrm{Y}=0,377+0,016 \mathrm{X}_{1}+(-0,017) \mathrm{X}_{2}+(0,005) \mathrm{X}_{3}+\mathrm{e}
$$

Dari persamaan regresi tersebut terlihat bahwa nilai konstanta adalah sebesar 0,377 . Hal ini menjelaskan bahwa apabila nilai dari leverage $\left(\mathrm{X}_{1}\right)$, pertumbuhan penjualan $\left(\mathrm{X}_{2}\right)$, dan ukuran perusahaan $\left(\mathrm{X}_{3}\right)$ dianggap nol, maka besarnya nilai dari ETR sebagai proksi dari tax avoidance adalah senilai 0,377 .

Nilai koefisien dari $X_{1}$ ialah sebesar 0,016 . Hal ini menjelaskan bahwa apabila nilai dari $X_{1}$ bertambah sebesar 1 sedangkan $\mathrm{X}_{2}$ dan $\mathrm{X}_{3}$ dianggap konstan, maka nilai dari $\mathrm{Y}$ akan meningkat sebesar 0,016 setiap adanya kenaikan dari $\mathrm{X}_{1}$.

Nilai koefisien dari $X_{2}$ ialah sebesar $-0,017$. Hal ini menjelaskan bahwa apabila nilai dari $X_{2}$ bertambah sebesar 1 sedangkan $\mathrm{X}_{1}$ dan $\mathrm{X}_{3}$ dianggap konstan, maka nilai dari $\mathrm{Y}$ akan menurun sebesar 0,017 setiap adanya kenaikan dari $\mathrm{X}_{2}$.

Nilai koefisien dari ukuran perusahaan ialah sebesar -0,005. Hal ini menjelaskan bahwa apabila nilai dari $\mathrm{X}_{3}$ bertambah sebesar 1 sedangkan $\mathrm{X}_{1}$ dan $\mathrm{X}_{2}$ dianggap konstan, maka nilai dari $\mathrm{Y}$ akan menurun sebesar 0,005 setiap adanya kenaikan dari $\mathrm{X}_{3}$.

Pengujian selanjutnya adalah uji t yang berfungsi mengunjukkan pengaruh variabel independen 
dengan variabel dependen secara parsial. Taraf signifikansi untuk uji t adalah 5\%. Sehingga kriteria pengujian ini ialah apabila besarnya signifikansi kurang atau sama dengan 0,05 maka secara signifikan variabel independen berpengaruh terhadap variabel dependen. Sedangkan apabila besarnya signifikansi lebih dari 0,05 maka variabel independen tidak berpengaruh signifikan terhadap variabel dependen.

Hasil uji $\mathrm{t}$ pada Tabel 7. untuk pengujian hipotesis memperlihatkan leverage beserta pertumbuhan penjualan berpengaruh signifikan terhadap tax avoidance sementara ukuran perusahaan tidak berpengaruh signifikan terhadap tax avoidance. Nilai DER berpengaruh positif terhadap ETR dengan besaran signifikansi 0,000. Nilai sales growth berpengaruh negatif terhadap ETR dengan besaran signifikansi 0,025 . Sedangkan nilai ukuran perusahaan berpengaruh negatif terhadap ETR dengan besaran signifikansi 0,055.

Selanjutnya adalah uji f yang berfungsi untuk mengunjukkan pengaruh variabel independen dengan variabel dependen secara simultan. Taraf signifikansi untuk uji $\mathrm{f}$ adalah $5 \%$ sehingga apabila nilai signifikan mengunjukkan kurang atau sama dengan 0,05 maka variabel independen secara simultan berpengaruh signifikan terhadap variabel dependen. Sedangkan apabila nilai signifikan mengunjukkan lebih dari 0,05 maka variabel independen secara simultan tidak berpengaruh signifikan terhadap variabel dependen.

Tabel 8. Uji F

\begin{tabular}{|c|c|c|c|c|c|c|}
\hline \multicolumn{7}{|c|}{ ANOVA $^{\mathrm{a}}$} \\
\hline \multicolumn{2}{|c|}{ Model } & Sum of Squares & $\mathrm{df}$ & Mean Square & $\mathrm{F}$ & Sig. \\
\hline \multirow[t]{3}{*}{1} & Regression & .054 & 3 & .018 & 6.597 & $.000^{\mathrm{b}}$ \\
\hline & Residual & .588 & 215 & .003 & & \\
\hline & Total & .642 & 218 & & & \\
\hline
\end{tabular}

Sumber: Output SPSS 26 (Data Diolah Peneliti, 2021)

Perolehan uji F pada Tabel 8. memperlihatkan bahwa leverage, pertumbuhan penjualan, dan ukuran perusahaan secara simultan berpengaruh terhadap tax avoidance. Secara simultan ketiga variabel independen berpengaruh positif terhadap ETR dengan nilai signifikansi 0,000.

Uji koefisien determinasi atau adjusted $\mathrm{R}^{2}$ terlihat pada Tabel 6. Hasil pengujian memperlihatkan nilai adjusted $\mathrm{R}^{2}$ sebesar 0,072 . Hal tersebut mengartikan bahwa besarnya pengaruh dari leverage, pertumbuhan penjualan, dan ukuran perusahaan secara simultan terhadap tax avoidance adalah sejumlah $7,2 \%$.

\section{PEMBAHASAN}

Penelitian memperoleh hasil bahwa secara signifikan leverage berpengaruh terhadap tax avoidance, alhasil hipotesis pertama diterima. Nilai koefisien memperlihatkan adanya hubungan positif antara DER dan ETR yang mengartikan bahwa semakin tinggi nilai dari DER maka akan semakin tinggi nilai dari ETR. Nilai DER yang tinggi memperlihatkan bahwa perusahaan memiliki tingkat leverage yang tinggi, sedangkan nilai ETR yang tinggi memperlihatkan tingkat tax avoidance yang rendah. Semakin tinggi leverage maka semakin rendah tingkat tax avoidance, sehingga leverage berpengaruh negatif terhadap tax avoidance. Perusahaan dengan leverage tinggi memiliki motif yang lebih sedikit dalam menghindari pajak karena telah menerima manfaat pajak atas beban bunga (Kim \& Im, 2017). Semakin tinggi leverage menimbulkan tingginya beban bunga yang akan berdampak pada berkurangnya beban pajak, sehingga secara tidak langsung perusahaan telah melakukan penghindaran pajak (Nugraha \& Mulyani, 2019). Perusahaan memanfaatkan pendanaan yang berasal dari utang kepada pihak lain untuk memanfaatkan beban bunganya guna memperkecil pajak. Hasil penelitian ini sejalan dengan (Dewi \& Noviari, 2017; Dharma \& Ardiana, 2016) bahwa leverage berpengaruh terhadap tax avoidance dan semakin tinggi leverage maka mengindikasikan rendahnya tingkat tax avoidance.

Penelitian memperoleh hasil bahwa secara signifikan pertumbuhan penjualan berpengaruh 
terhadap tax avoidance, alhasil hipotesis kedua diterima. Nilai koefisien memperlihatkan adanya hubungan negatif antara sales growth dan ETR yang mengartikan bahwa semakin tinggi nilai dari sales growth maka semakin rendah nilai dari ETR. Dalam hal ini berarti tingginya pertumbuhan penjualan menandakan peningkatan tingkat tax avoidance, sehingga pertumbuhan penjualan berpengaruh positif terhadap tax avoidance. Perubahan nilai penjualan perusahaan secara langsung akan mengubah laba sehingga akan berpengaruh pula kepada besaran pajak. Tingginya pertumbuhan memerlukan investasi baru dan pendanaan, sehingga perusahaan akan memiliki lebih banyak opsi untuk mencapai ETR yang rendah (Rodriguez, Fernandez, \& Arias, 2020). Hasil penelitian ini sejalan dengan (Januari \& Suardikha, 2019; Tristianto \& Oktaviani, 2016) bahwa pertumbuhan penjualan berpengaruh terhadap tax avoidance dan semakin tinggi tingkat pertumbuhan penjualan maka mengindikasikan tingginya tingkat tax avoidance.

Penelitian memperoleh hasil bahwa secara signifikan ukuran perusahaan tidak berpengaruh terhadap tax avoidance, alhasil hipotesis ketiga ditolak. Kecil ataupun besarnya skala perusahaan tidak berpengaruh dan berdampak pada perubahan tingkat tax avoidance perusahaan. Terlepas dari ukurannya, setiap perusahaan ialah wajib pajak yang mempunyai kewajiban untuk membayarkan pajak. Setiap wajib pajak akan mendapatkan sanksi apabila tidak mematuhi peraturan yang berlaku. Pengawasan fiskus tidak hanya berlaku untuk perusahaan besar, namun juga perusahaan kecil agar tetap mengikuti ketentuan perpajakan yang berlaku (Permata, Nurlaela, \& Wahyuningsih, 2018). Hasil penelitian ini sejalan dengan (Dewanti \& Sujana, 2019; Merslythalia \& Lasmana, 2016) bahwa ukuran perusahaan tidak berpengaruh terhadap tax avoidance.

Penelitian memperoleh hasil bahwa leverage, pertumbuhan penjualan, dan ukuran perusahaan secara simultan berpengaruh signifikan terhadap tax avoidance, alhasil hipotesis keempat diterima. Hal tersebut sesuai dengan (Kim \& Im, 2017) yang memperlihatkan bahwa karakteristik finansial perusahaan yang berhubungan dengan tax avoidance diantaranya adalah leverage, pertumbuhan penjualan, dan ukuran perusahaan. Selain itu (Rodriguez et al., 2020) mengunjukkan bahwa faktor yang mempengaruhi ETR adalah karakteristik tradisional (ukuran perusahaan, leverage, asset composition, profitabilitas) dan karakteristik yang lebih baru (pertumbuhan, manajemen laba, deferred tax). Ketiga variabel independen tersebut berdasarkan hasil penelitian dapat mempengaruhi tax avoidance sebesar 7.2\%, selebihnya dipengaruhi oleh faktor lain yang tidak dilibatkan dalam penelitian ini.

\section{KESIMPULAN}

Kesimpulan yang didapatkan berdasar pada hasil penelitian ialah bahwa leverage berpengaruh terhadap tax avoidance. Bertambahnya tingkat leverage akan menimbulkan peningkatan dari ETR yang mengartikan adanya penurunan tingkat tax avoidance perusahaan. Pertumbuhan penjualan berpengaruh terhadap tax avoidance. Bertambahnya pertumbuhan penjualan akan menimbulkan penurunan dari ETR yang mengartikan peningkatan tingkat tax avoidance perusahaan. Sementara ukuran perusahaan tidak berpengaruh terhadap tax avoidance. Terlepas dari ukurannya baik besar ataupun kecil, ukuran perusahaan tidak berdampak pada tax avoidance perusahaan. Serta leverage, pertumbuhan penjualan, dan ukuran perusahaan secara simultan berpengaruh signifikan terhadap tax avoidance sebesar 7,2\%.

\section{REFERENSI}

Anwar, M. (2019). Dasar-Dasar Manajemen Keuangan Perusahaan (1st ed.). Jakarta: Kencana.

Arianandini, P. W., \& Ramantha, I. W. (2018). Pengaruh Profitabilitas, Leverage, dan Kepemilikan Institusional pada Tax Avoidance. E-Jurnal Akuntansi Universitas Udayana, 22(3), 2018. https://doi.org/10.24843/eja.2018.v22.i03.p17

Ariawan, I. M. A. R., \& Setiawan, P. E. (2017). Pengaruh Dewan Komisaris Independen, Kepemilikan Institusional, Profitabilitas Dan Leverge Terhadap Tax Avoidance. E-Jurnal Akuntansi Universitas Udayana, 18(3), 1831-1859.

BPS. (2016). Sensus Ekonomi 2016. Retrieved from Badan Pusat Statistik website: https://se2016.bps.go.id/umkumb/

Budiman, R. (2018). Rahasia Analisis Fundamental Saham. Jakarta: PT Elex Media Komputindo. Dewanti, I. G. A. D. C., \& Sujana, I. K. (2019). Pengaruh Ukuran Perusahaan, Corporate Social 
Responsibility, Profitabilitas dan Leverage pada Tax Avoidance. E-Jurnal Akuntansi, 28(1), 377-406.

Dewi, N. L. P. P., \& Noviari, N. (2017). Pengaruh Ukuran Perusahaan, Leverage, Profitabilitas dan Corporate Social Responsibility Terhadap Penghindaran Pajak (Tax Avoidance). E-Jurnal Akuntansi Universitas Udayana, 830-859. https://doi.org/10.24843/EJA.2017.v21.i02.p01

Dharma, I. M. S., \& Ardiana, P. A. (2016). Pengaruh Leverage, Intensitas Aset Tetap, Ukuran Perusahaan, Dan Koneksi Politik Terhadap Tax Avoidance. E-Jurnal Akuntansi Universitas Udayana, 15(1), 584-613. Retrieved from https://ojs.unud.ac.id/index.php/Akuntansi/article/view/17463

Duli, N. (2019). Metodologi Penelitian Kuantitatif: Beberapa Konsep Dasar untuk Penulisan Skripsi \& Analisis Data dengan SPSS. Yogyakarta: Deepublish.

Farouq. (2018). Hukum Pajak di Indonesia: Suatu Pengantar Ilmu Hukum Terapan di Bidang Perpajakan. Jakarta: Kencana.

Fauzan, Wardan, D. A., \& Nurharjanti, N. N. (2019). The Effect of Audit Committee, Leverage, Return on Assets, Company Size, and Sales Growth on Tax Avoidance. Riset Akuntansi Dan Keuangan Indonesia, 4(3), 171-185. https://doi.org/10.23917/reaksi.v4i3.9338

Harahap, S. S. (2016). Analisis Kritis Laporan Keuangan. Jakarta: Rajawali Pers.

Hery, H. (2015). Analisis Kinerja Manajemen. Jakarta: Grasindo.

Irianto, B. S., Sudibyo, Y. A., \& Wafirli, A. (2017). The Influence of Profitability, Leverage, Firm Size and Capital Intensity Towards Tax Avoidance. International Journal of Accounting and Taxation, 5(2), 33-41. https://doi.org/10.15640/ijat.v5n2a3

Januari, D. M. D., \& Suardikha, I. M. S. (2019). Pengaruh Corporate Social Responsibility, Sales Growth, dan Profitabilitas Terhadap Tax Avoidance. E-Jurnal Akuntansi Universitas Udayana, 27(3), 1653-1677. https://doi.org/10.24843/EJA.2019.v27.i03.p01

Kim, J. H., \& Im, C. C. (2017). The Study On The Effect And Determinants Of Small - And Medium-Sized Entities Conducting Tax Avoidance. The Journal of Applied Business Research, 33(2), 375-390.

Kimsen, K., Kismanah, I., \& Masitoh, S. (2018). Profitability, Leverage, Size of Company Towards Tax Avoidance. JIAFE (Jurnal Ilmiah Akuntansi Fakultas Ekonomi), 4(1), 29-36. https://doi.org/10.34204/jiafe.v4i1.1075

Lukman, M. (2018). Keuangan Korporat: Teori dan Praktik di Indonesia. Jakarta: Bumi Aksara.

Mahdiana, M. Q., \& Amin, M. N. (2020). Pengaruh Profitabilitas, Leverage, Ukuran Perusahaan, dan Sales Growth Terhadap Tax Avoidance. Jurnal Akuntansi Trisakti, 7(1), 127. https://doi.org/10.25105/jat.v7i1.6289

Merslythalia, D. R., \& Lasmana, M. S. (2016). Pengaruh Kompetensi Eksekutif, Ukuran Perusahaan, Komisaris Independen, dan Kepemilikan Institusional Terhadap Tax Avoidance. Jurnal Ilmiah Akuntansi Dan Bisnis, 11(2), 117-124. https://doi.org/10.24843/JIAB.2016.v11.i02.p07

Morissan. (2017). Metode Penelitian Survei. Jakarta: Kencana.

Nibras, J. M., \& Hadinata, S. (2020). Pengaruh Profitabilitas, Leverage, Ukuran Perusahaan, Reputasi Auditor, Dan Capital Intensity Terhadap Tax Avoidance. Profita: Komunikasi Ilmiah Akuntansi Dan Perpajakan, 13(2), 165-178. https://doi.org/10.22441/profita.2020.v13i2.001

Nugraha, M. I., \& Mulyani, S. D. (2019). Peran Leverage Sebagai Pemediasi Pengaruh Karakter Eksekutif, Kompensasi Eksekutif, Capital Intensity, dan Sales Growth Terhadap Tax Avoidance. Jurnal Akuntansi Trisakti, 6(2), 301-324. https://doi.org/10.25105/jat.v6i2.5575

Oktamawati, M. (2017). Pengaruh Karakter Eksekutif, Komite Audit, Ukuran Perusahaan, Leverage, Pertumbuhan Penjualan, Dan Profitabilitas Terhadap Tax Avoidance. Jurnal Akuntansi Bisnis, 15(1), 23-40. https://doi.org/10.24167/jab.v15i1.1349

Permata, A. D., Nurlaela, S., \& Wahyuningsih, E. M. (2018). Pengaruh Size, Age, Profitability, Leverage dan Sales Growth Terhadap Tax Avoidance. Jurnal Akuntansi Dan Pajak, 19(1), 10-20. https://doi.org/10.29040/jap.v19i1.171

Pohan, C. A. (2018). Optimizing Corporate Tax Management: Kajian Perpajakan dan Tax 
Planning-nya Terkini. Jakarta: Bumi Aksara.

Pramukti, A. S., \& Primaharsya, F. (2015). Pokok-Pokok Hukum Perpajakan. Yogyakarta: Medpress Digital.

Purwanti, S. M., \& Sugiyarti, L. (2017). Pengaruh Intensitas Aset Tetap, Pertumbuhan Penjualan dan Koneksi Politik Terhadap Tax Avoidance. Jurnal RIset Akuntansi \& Keuangan, 5(3), 1625-1642. https://doi.org/10.17509/jrak.v5i3.9225

Puspita, D., \& Febrianti, M. (2017). Faktor-Faktor yang Memengaruhi Penghindaran Pajak pada Perusahaan Manufaktur di Bursa Efek Indonesia. Jurnal Bisnis Dan Akuntansi, 19(1), 38-46. https://doi.org/10.34208/jba.v19i1.63

Rahayu, S. K. (2020). Perpajakan: Konsep, Sistem dan Implementasi. Bandung: Rekayasa Sains.

Rodriguez, E. F., Fernandez, R. G., \& Arias, A. M. (2020). Business and Institutional Determinants of Effective Tax Rate in Emerging Economies. Economic Modelling. https://doi.org/10.1016/j.econmod.2020.02.011

Setyawan, S. (2020). Perpajakan: Pengantar, KUP, Pajak Penghasilan, PPN \& PPN-BM, Pajak Bea Materai, Pajak \& Retribusi Daerah. Malang: UMM Press.

Sudaryo, Y., Sjarif, D., \& Sofiati, N. A. (2017). Keuangan di Era Otonomi Daerah. Yogyakarta: Andi.

Sulistyanto, S. (2018). Manajemen Laba: Teori dan Model Empiris. Jakarta: Grasindo.

Tang, T. Y. H. (2020). A review of tax avoidance in China. China Journal of Accounting Research, 13(4), 327-338. https://doi.org/10.1016/j.cjar.2020.10.001

Tax Justice. (2020). The State of Tax Justice 2020: Tax Justice in the time of COVID-19. (November). Retrieved from https://www.taxjustice.net/reports/the-state-of-tax-justice-2020/

Tristianto, D., \& Oktaviani, R. M. (2016). Faktor-Faktor yang Mempengaruhi Tax Avoidance dengan Leverage sebagai Variabel Mediasi. Dinamika Akuntansi, Keuangan Dan Perbankan, 5(1), 65-81. Retrieved from https://www.unisbank.ac.id/ojs/index.php/fe9/article/view/5572 